\title{
Effects of Heavy Metal Pollution on Omega-3 Polyunsaturated Fatty Acids Levels In Tilapia Fish from Winam Gulf of Lake Victoria
}

\author{
V. M. Muinde ${ }^{1}$, E. K. Nguu ${ }^{2, *}$, D. O. Ogoyi ${ }^{3}$ and P. M. Shiundu ${ }^{1,3}$ \\ ${ }^{I}$ Department of Chemistry, University of Nairobi, P.O. Box 30197-00100, Nairobi, Kenya \\ ${ }^{2}$ Department of Biochemistry, University of Nairobi, P.O. Box 30197-00100, Nairobi, Kenya \\ ${ }^{3}$ Department of Biochemistry and Biotechnology, Technical University of Kenya, P.O. BOX 52428- 00200, Nairobi, \\ Kenya
}

\begin{abstract}
Winam Gulf is facing major pollution threats from anthropogenic input of pollutants such as heavy metals and agrochemical residues. This has deleterious effects on flora and fauna in the lake and consequently the quality of omega 3 polyunsaturated fatty acids (PUFAs) which have numerous health benefits in humans. In addition, heavy metal bioaccumulation in fish poses a threat to human health. The major objective of the study was to establish whether there is a correlation between the heavy metal pollutants and the levels of omega - 3 PUFAs in fish. Levels of heavy metals - lead, cadmium, Zinc and chromium in sediments, water, and tilapia from selected sites in Winam Gulf were investigated. They were analyzed using Atomic Absorption Spectrophotometer. Fish muscles were further analyzed for omega -3 PUFAs using gas chromatography. Sediment samples accumulated the highest levels of heavy metals ranging from below detection limit to as high as $277 \mathrm{mg} / \mathrm{kg}$ on dry weight basis. Zinc levels in fish muscles were the highest whereas cadmium was the lowest. Heavy metal levels in water were found to be lowest compared to sediments and fish. Omega-3 PUFAs, particularly alpha-linolenic, eicosapentaenoic, docosapentaenoic and docosahexaenoic acids were in substantial amounts in fish. Oil contents were in the range of $(2.47-3.87) \%$. There was no clear link observed between the levels of heavy metals and omega-3 PUFAs in fish although the fish muscles showed presence of these metals.
\end{abstract}

Keywords: Omega -3 PUFAs, Heavy metals, pollution, Lake Victoria, fish, sediments, water.

\section{INTRODUCTION}

Lake Victoria is the largest fresh water lake in Africa with a surface area of $68,000 \mathrm{Km}^{2}$ and distributed among Kenya (6\%), Uganda (43\%) and Tanzania (51\%), [1-4]. The lake is shallow with a depth of $69 \mathrm{~m}$. It is fed by a number of large rivers in Kenya, (Nzoia, Gucha-migori, Sondu-Miriu, Mara, Yala and Nyando), while River Nile is the single outlet [5].

The lake is of very high economic importance since it is a source of food in form of fish to the inhabitants who live along the lake basin and Kenyan population at large [3, 6]. It is also a source of energy, drinking and irrigation water and transport. The lake resources have also provided amenities for cultural activities as well as leisure [7]. However, the lake is under serious threat due to heavy metal pollution from natural and anthropogenic sources [8-10]. Ogoyi et al. [4] recently reported presence of heavy metals in water, sediments and microalgae samples from both Winam and Mwanza Gulfs of Lake Victoria. Their work indicated that

*Address correspondence to this author at the Department of Biochemistry, University of Nairobi, P.O. Box 30197-00100, Nairobi, Kenya;

Tel/Fax: +254-20-4442841; E-mail: ednguu@uonbi.ac.ke
Lake Victoria basin has significant basal contamination levels even though they do not reach those of clearly polluted areas. Tole and Shitsama [11] in a previous study did some work on heavy metals in water, fish and sediments from Winam Gulf and indicated that the source of the heavy metals was mainly from urban industrial areas. However, none of these studies focused on linking the heavy metal pollution in the lake to the levels of polyunsaturated fatty acids (PUFAs) in fish to assess if there was any effect.

The pollution in the lake is a problem which demands urgent interventions to avoid bioaccumulation of pollutants in fish and in the primary producers such as algae which are the basic food for the fish. Nile tilapia (Oreochromis niloticus) is one of the most consumed species among the Lake Victoria fish species. Its popularity is simply because it is a major source of essential omega-3- polyunsaturated fatty acids(PUFAs); namely docosahexaenoic acid (DHA), eicosapentaenoic acid, (EPA) and alpha linolenic acid (ALA) [2, 1214] which are associated with numerous health benefits [20].

The objectives of the present study were to investigate the types and levels of omega- 3 PUFAs in tilapia fish and also determine heavy metal concentrations in Lake Victoria sediments, water and fish. The work also focused on estab- 


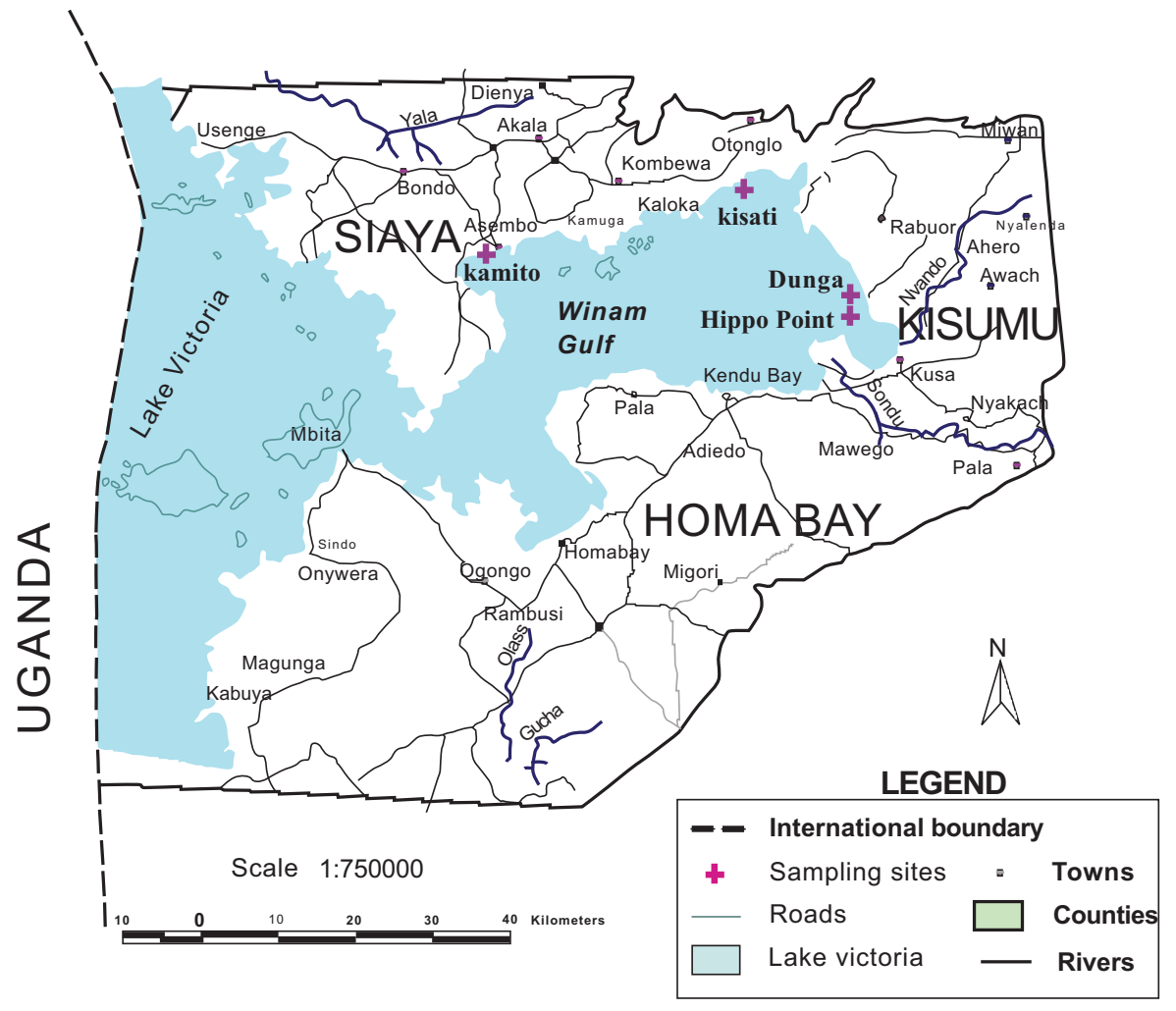

Fig. (1). Sampling points within Winam Gulf, Lake Victoria.

lishing whether there is any correlation between heavy metal concentrations and the fatty acid levels in the fish.

\section{MATERIALS AND METHODS}

\section{Study Area}

The study area was in Winam Gulf of Lake Victoria, Kenya (Fig. 1) which lies within latitudes $0^{\circ} 11.2^{\prime} \mathrm{N}-1^{\circ} 12.6^{\prime} \mathrm{S}$ and longitudes $33^{\circ} 45.7^{\prime} E-34^{\circ} 45.7^{\prime}$ E. Samples of sediments, tilapia fish (Oreochromis niloticus) and water were collected from four (4) sampling sites namely; Hippo point (on $0^{\circ} 07^{\prime}$ latitude and $\left.34^{\circ} 44^{\prime} \mathrm{E}\right)$, Kisati $\left(0^{\circ} 06^{\prime}\right.$ latitude and $\left.34^{\circ} 44^{\prime} \mathrm{E}\right)$, Dunga point (on $0^{\circ} 08^{\prime}$ latitude and $34^{\circ} 44^{\prime} \mathrm{E}$ ) and KamitoAsembo bay $\left(0^{\circ} 11^{\prime}\right.$ latitude and $\left.34^{\circ} 23^{\prime} \mathrm{E}\right)$.

The sites were chosen based on human activities near them which are considered to be the source of pollutants to the lake. Hippo point is located near a sewer line which discharges municipal sewage to the lake whereas Kisati is the major recipient of industrial effluents through River Kisati. Kamito sampling site is near an old gold mine while Dunga point was considered less polluted compared to the other three sites according to available literature $[8,9]$.

\section{SAMPLING}

Sampling of water, sediment and tilapia fish (Oreochromis niloticus) was carried out in May 2010(long rain), November 2010 (short rain) and early April 2011 (dry season) in four sampling sites described above. Water samples were collected in quadruplicates from each site into $1 \mathrm{~L}$ plastic bottles which were previously pre- cleaned with dilute nitric acid, (1: $1 \mathrm{v} / \mathrm{v})$ and rinsed well using double distilled- deionized water. $\mathrm{pH}$ of the water and dissolved oxygen (DO) were measured onsite. The $\mathrm{pH}$ ranged from $6.3 \pm 0.20$ to $9.04 \pm 0.20$ whereas the DO ranged from $3.59 \pm 0.30$ to $11.62 \pm 1.60$.

The water samples were then mixed with $2 \mathrm{~mL}$ of concentrated nitric acid (AR 69-70\%) to lower the $\mathrm{pH}$ to $\mathrm{pH}<2$ $[6,16,17]$. They were then transported in cooler boxes to the laboratory where they were maintained at $-20{ }^{\circ} \mathrm{C}$ prior to analysis. Sediment samples were collected in quadruplicates, at the same site as water samples using a stainless steel Eckman grab sampler and stored in labeled polypropylene bottles and then kept in ice box for transportation to the laboratory where they were preserved in a deep freezer $\left(-20^{\circ} \mathrm{C}\right)$ awaiting analysis. The $\mathrm{pH}$ of the sediments was measured in the laboratory and ranged from $6.2 \pm 0.09$ to 7.2 .

Fish was sampled using electronic fishing method in Kisati, Dunga and Hippo point whereas in Kamito - Asembo Bay, it was done by use of trawling nets. Fish was weighed to the nearest gram and length measured to the nearest millimeter on site. The length of the fish ranged from $12.5-28.0$ $\mathrm{cm}$ and the weight ranged from $26.21-435 \mathrm{~g}$. The samples were put in well labeled black polythene bags and then transported to the laboratory in cooler boxes with layers of ice and kept at $-20^{\circ} \mathrm{C}$ prior to analysis.

\section{HEAVY METAL ANALYSIS}

Samples were thawed separately. About $20 \mathrm{~g}$ of both sediments and fish samples were dried to constant weight in an oven at $105^{\circ} \mathrm{C}$ and homogenized using mortar and pestle. Triplicate samples, $1 \mathrm{~g}$ each, of both sediments and fish were 


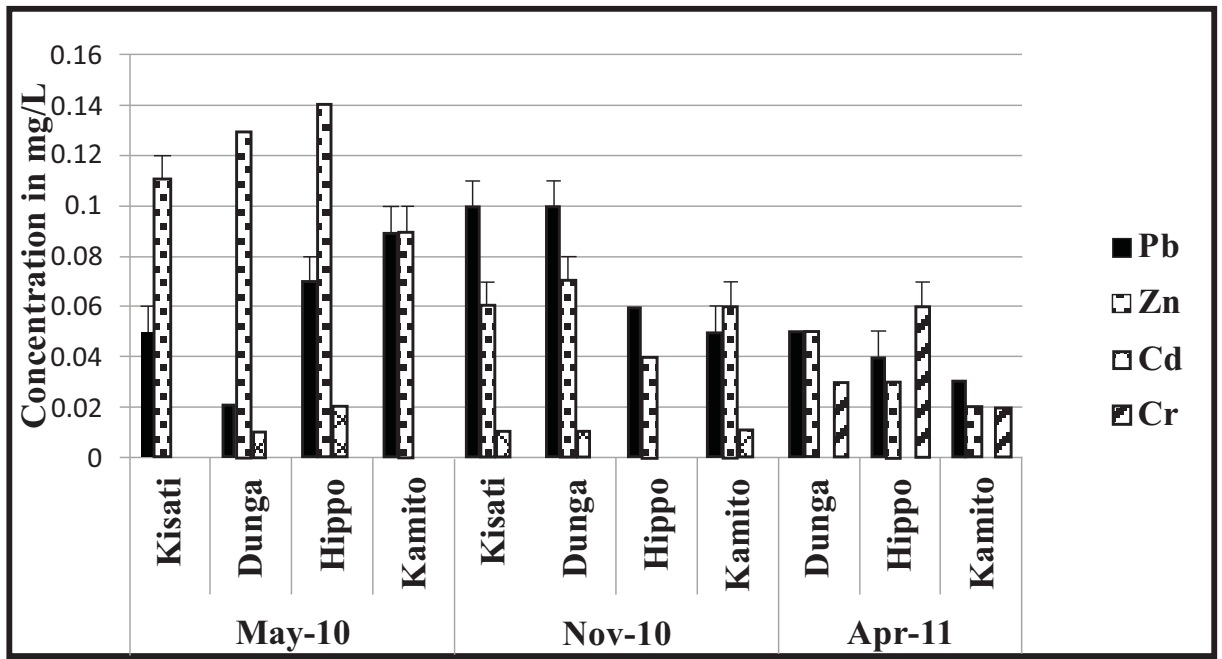

Fig. (2). Heavy metal concentrations $(\mathrm{mg} / \mathrm{L})$ in water from Winam Gulf.

digested in $10 \mathrm{~mL}$ aqua regia mixture - concentrated hydrochloric and nitric acids, $\left(\mathrm{HCl}: \mathrm{HNO}_{3}\right.$, both of Analar grade from Sigma - Adrich Chemicals) in the ratio of $3: 1$ and $1 \mathrm{~mL}$ perchloric acid (Fisher Scientific Ltd) in digestion tubes using a hot plate for $3 \mathrm{hrs}$ at $60{ }^{\circ} \mathrm{C}$ [8].

$100 \mathrm{~mL}$ of unfiltered water samples was measured in triplicates and digested using $10 \mathrm{~mL}$ of aqua regia and $1 \mathrm{~mL}$ of perchloric acid. All the samples were cooled and filtered into $50 \mathrm{~mL}$ volumetric flasks using What man No 1 filter papers and made up to volume with double distilled - deionized water. The extracts were analyzed for cadmium $(\mathrm{Cd})$, lead $(\mathrm{Pb})$, zinc $(\mathrm{Zn})$ and chromium $(\mathrm{Cr})$ using atomic absorption spectrophotometer (Varian Spectra 10, Techtron Pty. Ltd Springvale, Australia) at 228.8, 217, 213.9 and 357.9 $\mathrm{nm}$, respectively $[17,18]$.

\section{EXTRACTION OF OILS FROM FISH}

Fish muscles were separately homogenized at ambient temperature using a warring blender. Oil was extracted using Folch method in chloroform: methanol in the ratio of $2: 1 \mathrm{v} / \mathrm{v}$ [19]. The excess solvent from the samples was removed with a rotary evaporator (Barloworld Scientific Ltd, Staffordshire ST 15 OSA, UK) and the oil contents determined gravimetrically [19].

\section{GAS CHROMATOGRAPHY ANALYSIS}

Fatty acid methyl esters (FAME) were prepared using acid methanolysis method [19]. The fatty acid analysis from fish samples was done using Varian CP 3800 gas chromatography, (Walnut Creek, CA, USA), which was equipped with flame ionization detector, (FID). Supelcowax 10 capillary column (60 m x $0.32 \mathrm{~mm} \times 0.25 \mu \mathrm{m}$ film thickness; Supelco, Bellefonte, PA, USA) was used to separate fatty acid methyl esters. $1 \mu \mathrm{L}$ of FAME in hexane was injected into the gas chromatography (GC) equipment in a splitless mode. Helium was used as the carrier gas at a flow rate of $2 \mathrm{~mL} / \mathrm{min}$, [20]. The injector and the detector were maintained at $250{ }^{\circ} \mathrm{C}$ and $260{ }^{\circ} \mathrm{C}$ respectively. Temperature was programmed as follows: column oven was set at $35^{\circ} \mathrm{C}$, held for 3 minutes and then increased to $240{ }^{\circ} \mathrm{C}$ at a rate of $10{ }^{\circ} \mathrm{C} / \mathrm{min}$ and held for 41.5 minutes.

A quantitative assay of fatty acids was achieved by comparison of analyte GC signals to corresponding signals of authentic standard mixture of FAME, Qualmix fish S, (Larodan Fine Chemicals AB, Malmö, Sweden). Response factors of different FAME were calculated from analysis of the standard mixture and were subsequently used to calculate the relative amounts of different fatty acids in each sample based on mol \%. Methyl tridecanoate, (C13), was used as the internal standard. Quantification was performed using Varian star software 5.5, (Walnut Creek, CA, USA). All the samples were analyzed in triplicates.

\section{RESULTS}

\section{Heavy Metal Analysis}

The heavy metal concentrations as determined from water, sediments and fish samples are given in Figs. (2, 3 and 4) respectively. The data shows clearly that the concentrations of heavy metals in sediments are much higher than in either fish or water samples. Concentrations of heavy metals in water are expressed in $\mathrm{mg} / \mathrm{L}$ whereas in fish and sediments, they are expressed as $\mathrm{mg} / \mathrm{kg}$ of dry weight. Zinc metal had the highest levels whereas cadmium had the lowest in sediments. The highest concentration of lead in sediments $(85$ $\pm 1.73 \mathrm{mg} / \mathrm{kg}$ ) was recorded in Kisati in November 2010. For Zinc the lowest levels were detected in Hippo point (36.7 \pm $1.53 \mathrm{mg} / \mathrm{kg}$ ) whereas the highest levels were detected in Kisati sampling point $(277 \pm 1.53 \mathrm{mg} / \mathrm{kg})$. Cadmium ranged from below detection limit to $3.3 \pm 0.50 \mathrm{mg} / \mathrm{kg}$ whereas for chromium the highest concentration was detected in Kamito $(21.0 \pm 0.70 \mathrm{mg} / \mathrm{kg})$. The results showed a correlation $(\mathrm{p}<$ $0.05)$ between $\mathrm{Pb}$ and $\mathrm{Zn}, \mathrm{Zn}$ and $\mathrm{Cr}$ in sediments. The trend of heavy metal abundance in sediments was $\mathrm{Zn}>\mathrm{Pb}>\mathrm{Cr}>$ Cd.

Fish has been considered to be good indicators for heavy metal contamination in aquatic systems because they occupy different trophic levels with different sizes and age. There 


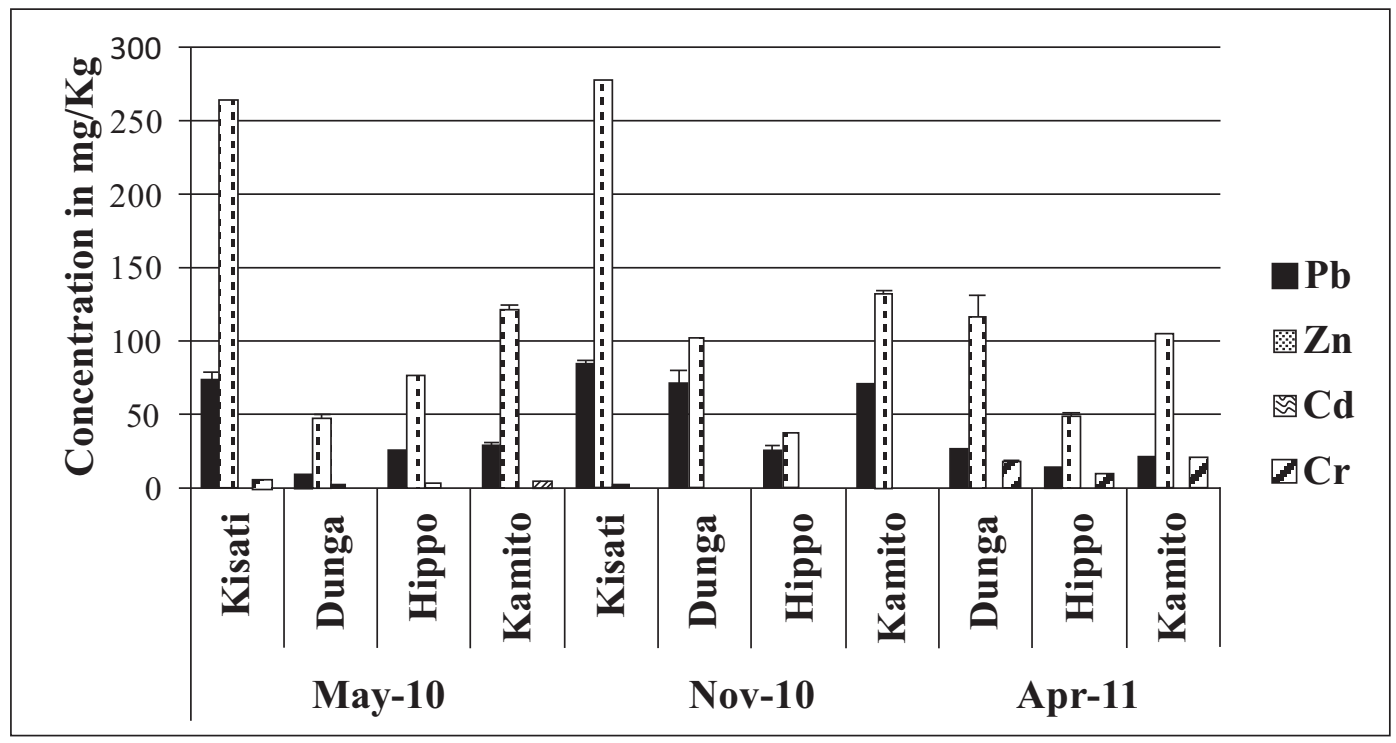

Fig. (3). Heavy metal concentrations $(\mathrm{mg} / \mathrm{kg})$ in sediments from Winam Gulf.

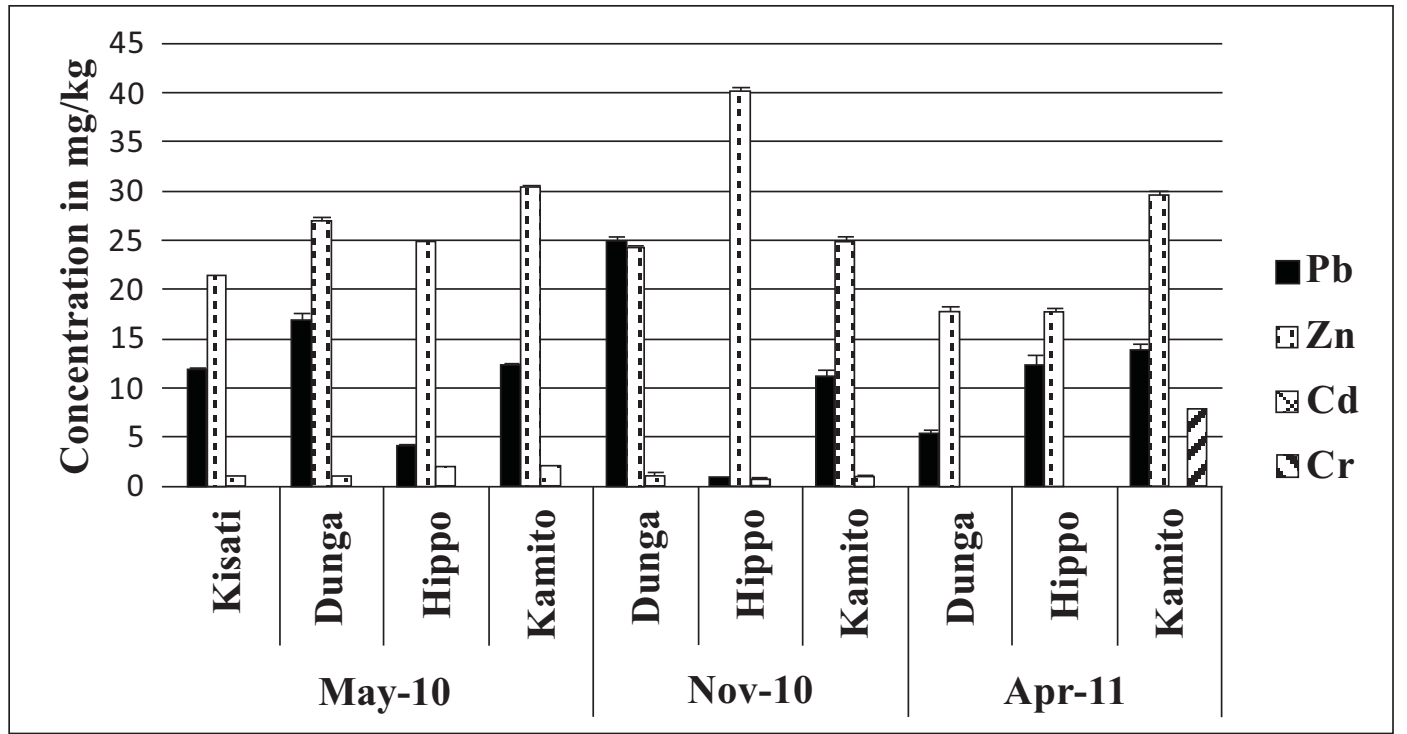

Fig. (4). Heavy metal concentrations $(\mathrm{mg} / \mathrm{kg})$ in tilapia fish (Orechromis niloticus) from Winam Gulf.

was no clear correlation $(p>0.05)$ in the concentrations of heavy metals analyzed but the heavy metal trend in fish followed: $\mathrm{Zn}>\mathrm{Pb}>\mathrm{Cd}>\mathrm{Cr}$. Dunga point had the highest levels of lead in fish $(24.7 \pm 0.57 \mathrm{mg} / \mathrm{kg})$ whereas for zinc metal the highest levels were recorded in Hippo point $(40.0 \pm 0.50$ $\mathrm{mg} / \mathrm{kg})$. The highest concentration of cadmium $(1.93 \pm 0.10$ $\mathrm{mg} / \mathrm{kg}$ ) was recorded in both Hippo point and Kamito (Fig. 4). Chromium ranged from below detection to $7.80 \pm 0.70$ $\mathrm{mg} / \mathrm{kg}$.

Water recorded the lowest levels of all heavy metals analyzed. There was no correlation observed in the heavy metals analyzed in Lake Victoria water $(\mathrm{p}>0.05)$. The highest lead levels in water were detected in Kisati $(0.1 \pm 0.01 \mathrm{mg} / \mathrm{L})$ in November 2010 whereas highest levels of zinc were detected in Hippo point $(0.14 \pm 0.00 \mathrm{mg} / \mathrm{L})$ in May 2010 . Cadmium ranged from below detection to $0.02 \pm 0.00 \mathrm{mg} / \mathrm{L}$ in Hippo point and the highest levels of chromium $(0.06 \pm 0.00 \mathrm{mg} / \mathrm{L})$ were detected in same sampling site (Hippo point). The heavy metal trend in water followed: $\mathrm{Zn}>\mathrm{Pb}>\mathrm{Cr}>\mathrm{Cd}$. Overall, it was found that the trends for heavy metal accumulation in both sediment and water samples were similar, that is $\mathrm{Zn}>\mathrm{Pb}>\mathrm{Cr}>\mathrm{Cd}$ whereas for fish samples the trend was $\mathrm{Zn}>\mathrm{Pb}>\mathrm{Cd}>\mathrm{Cr}$.

\section{FATTY ACID PROFILE IN NILE TILAPIA MUSCLES}

The oil contents (mol \%) of muscles of tilapia fish from Winam Gulf are represented in Table 1. Fish are often classified on the basis of their oil content. Based on this classification, lean fish have lower than $5 \%$ oil content, whereas fatty fish have more than $5 \%$ oil content [14]. The oil contents were in the range of $2.45 \pm 0.07$ to $3.87 \pm 0.11 \%$ on wet basis. These levels are lower than those reported by Masa et al. [14] where the oil content from Nile tilapia muscle from Lake Victoria, Uganda was $5.23 \pm 0.47 \%$ and therefore was 
Table 1. Mean Percentage (\%) oil Content in the Muscles of Tilapia fish (Oreochmis niloticus) from Winam Gulf

\begin{tabular}{|c|c|c|c|}
\hline Sampling site & May 2010 & November 2010 & April 2011 \\
\hline \hline Kisati & $2.61 \pm 0.05$ & - & $2.47 \pm 0.11$ \\
\hline Hippo & $2.45 \pm 0.07$ & $2.56 \pm 0.99$ & $2.85 \pm 0.14$ \\
\hline Dunga & $3.87 \pm 0.11$ & $2.77 \pm 0.15$ & $2.68 \pm 0.17$ \\
\hline Kamito & $2.78 \pm 0.09$ & $2.56 \pm 0.99$ & \\
\hline
\end{tabular}

Data derived from analysis of fish muscles of tilapia fish. Values are averages of three replicates \pm standard deviation.

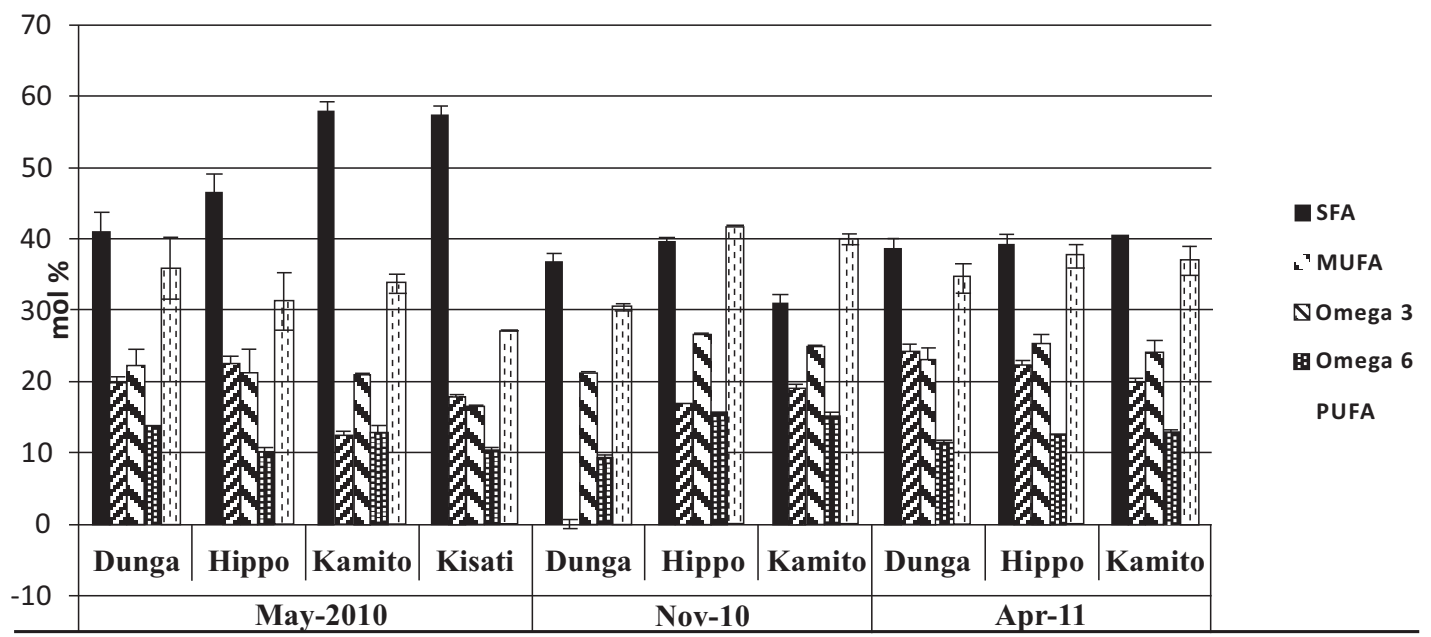

Fig. (5). Levels of fatty acids (mol \%) in tilapia fish from different sampling sites in Winam Gulf.

classified as fatty fish. The tilapia fish in the present study was classified as lean fish since the oil content was lower than $5 \%$. The low concentrations of lipid in the muscles of the tilapia fish reported here could be due to the utilization of fat reserves during normal body activities and the ecology as well [21]. Statistical analysis by ANOVA two way showed that there was no significant site variation in oil levels $(p>$ $0.05)$.

Dunga point fish recorded the highest oil content of $3.87 \pm 0.11 \%$ whereas Hippo point recorded the lowest in May 2010 samples (Table 1). In November 2010 the oil contents ranged from $2.56 \pm 0.99-2.77 \pm 0.15 \%$ whereas in April 2011 the fish samples from Dunga point recorded the highest oil content of $2.85 \pm 0.14$ compared to Hippo point which had the lowest values of $2.47 \pm 0.11$. No fish samples were collected from Kisati in November 2010 and April 2011 due to complete blockage of the sampling site by water hyacinth which hampered boat navigation to the site.

Fatty acid composition of oils from Nile tilapia (mol \%) is shown in Table 2 . In total, 17 fatty acids (FAs) were identified in the muscles of tilapia fish from Winam Gulf. The saturated (SFA) fraction was higher (31.1 - 57.9 mol \%) than the polyunsaturated fatty acid (PUFA) fraction (26.9 $41.7 \mathrm{~mol} \%$ ). The most prominent SFA was palmitic acid (C16:0) ranging from $(21.4-43.7 \mathrm{~mol} \%)$. Odd number SFA pentadecanoic acid (C15:0) was present in small amounts $(0.5 \pm 0.01-2.4 \pm 0.06 \mathrm{~mol} \%)$. The dominant monounsatu- rated fatty acids (MUFA) were palmitoleic C 16:1 (3.0 \pm 0.31 $-12.7 \pm 0.66 \mathrm{~mol} \%)$ and Oleic acids C 18:1 n $9(4.3 \pm 0.19-$ $12.0 \pm 0.03 \mathrm{~mol} \%)$.

Among the PUFAs docosahexaenoic acid (DHA), C 22:6 n 3; eicosahexaenoic acid (EPA), C 20:5 n 3; docosapentaenoic acid (DPA), C 22:5 n 3; and alpha-linolenic acid (ALA), C 18:3 n 3 were the most dominant omega-3 fatty acids in Nile tilapia oils (Table 2). The PUFAs also contained substantial amounts of omega-6, mainly arachidonic acid (20:4 n 6) and adrenic acid (C 22: 4 n 6) with the former being the major omega-6 PUFA with the concentration varying from $(3.7 \pm 0.14-10.5 \pm 0.30 \mathrm{~mol} \%)$.

The ratio of PUFA/SFA ranged from 0.47 to 1.28 whereas the ratio of omega 3 to omega 6 ranged from 1.63 to 2.27. The levels of fatty acids in Nile tilapia oil were in the order SFA > MUFA > PUFA.

No significant correlation ( $\mathrm{p}>0.05)$ was observed between the levels of polyunsaturated fatty acids (PUFAs) and the concentrations of heavy metals in this study although the analysis revealed presence of metals in fish muscles. Also there was no significant difference $(p>0.05)$ in levels of saturated fatty acids (SFAs), monounsaturated fatty acids (MUFAs) and polyunsaturated fatty acid (PUFAs) in relation to the sampling sites.

Fig. (5) represents the sum totals of various fatty acids (FAs) in tilapia fish from different sampling sites in Winam 
Table 2. Fatty acid composition (mol \%) in Nile tilapia from Winam Gulf, Lake Victoria in May 2010, November 2010 and April 2011

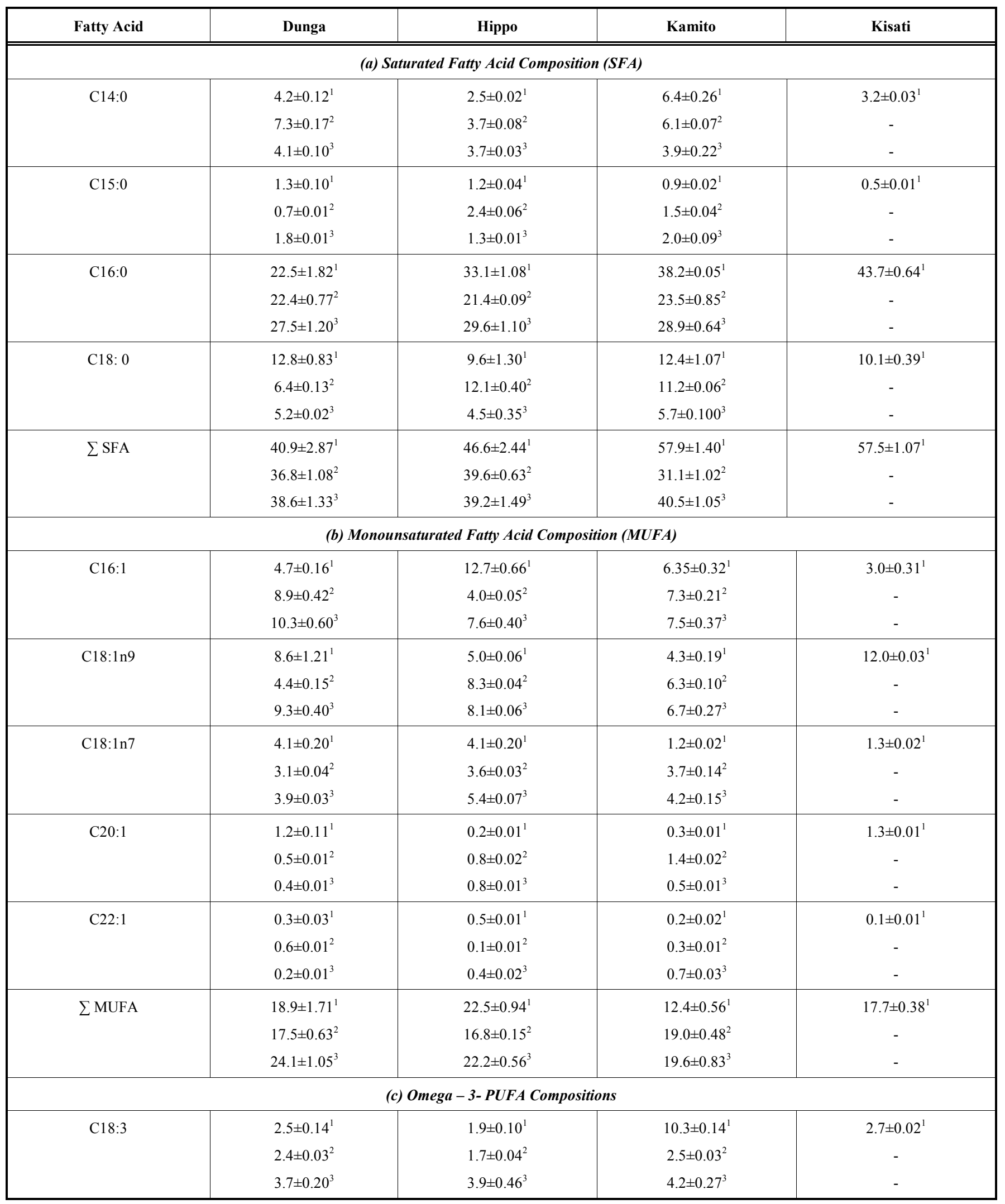


Table 2. contd...

\begin{tabular}{|c|c|c|c|c|}
\hline Fatty Acid & Dunga & Hippo & Kamito & Kisati \\
\hline \multirow{3}{*}{ C18:4 } & $0.7 \pm 0.01^{1}$ & $0.5 \pm 0.01^{1}$ & $0.7 \pm 0.02^{1}$ & $0.3 \pm 0.01^{1}$ \\
\hline & $0.4 \pm 0.01^{2}$ & $2.4 \pm 0.02^{2}$ & $3.1 \pm 0.01^{2}$ & - \\
\hline & $1.0 \pm 0.01^{3}$ & $1.7 \pm 0.02^{3}$ & $1.5 \pm 0.11^{3}$ & - \\
\hline \multirow{3}{*}{ C20:5 } & $4.0 \pm 0.16^{1}$ & $4.4 \pm 0.73^{1}$ & $2.7 \pm 0.03^{1}$ & $1.7 \pm 0.03^{1}$ \\
\hline & $3.2 \pm 0.03^{2}$ & $6.6 \pm 0.01^{2}$ & $4.2 \pm 0.02^{2}$ & - \\
\hline & $5.5 \pm 0.60^{3}$ & $4.2 \pm 0.35^{3}$ & $4.9 \pm 0.21^{3}$ & - \\
\hline \multirow{3}{*}{$\mathrm{C} 22: 5$} & $2.2 \pm 0.07^{1}$ & $4.8 \pm 0.80^{1}$ & $3.2 \pm 0.05^{1}$ & $2.6 \pm 0.02^{\mathrm{a}}$ \\
\hline & $4.8 \pm 0.08^{2}$ & $4.6 \pm 0.03^{2}$ & $3.2 \pm 0.03^{2}$ & - \\
\hline & $2.5 \pm 0.02^{3}$ & $3.6 \pm 0.04^{3}$ & $2.9 \pm 0.04^{3}$ & - \\
\hline \multirow{3}{*}{$\mathrm{C} 22: 6$} & $12.8 \pm 1.9^{1}$ & $9.6 \pm 1.60^{1}$ & $4.1 \pm 0.04^{1}$ & $9.2 \pm 0.05^{\mathrm{a}}$ \\
\hline & $10.3 \pm 0.10^{2}$ & $10.9 \pm 0.04^{2}$ & $11.8 \pm 0.16^{2}$ & - \\
\hline & $10.3 \pm 0.92^{3}$ & $11.8 \pm 0.47^{3}$ & $10.6 \pm 0.97^{3}$ & - \\
\hline \multirow{3}{*}{$\sum$ Omega - 3} & $22.2 \pm 2.28^{1}$ & $21.2 \pm 3.24^{1}$ & $21.0 \pm 0.28^{1}$ & $16.5 \pm 0.13^{1}$ \\
\hline & $21.1 \pm 0.25^{2}$ & $26.6 \pm 0.14^{2}$ & $24.8 \pm 0.25^{2}$ & - \\
\hline & $23.0 \pm 1.75^{3}$ & $25.2 \pm 1.35^{3}$ & $24.1 \pm 1.60^{3}$ & - \\
\hline \multicolumn{5}{|c|}{ (d) Omega-6-PUFA Compositions } \\
\hline \multirow{3}{*}{$\mathrm{C} 18: 2$} & $1.9 \pm 0.10^{1}$ & $3.1 \pm 0.11^{1}$ & $2.9 \pm 0.13^{1}$ & $4.7 \pm 0.01^{1}$ \\
\hline & $1.8 \pm 0.30^{2}$ & $3.4 \pm 0.01^{2}$ & $2.8 \pm 0.21^{2}$ & - \\
\hline & $2.5 \pm 0.04^{3}$ & $1.9 \pm 0.04^{3}$ & $3.7 \pm 0.34^{3}$ & - \\
\hline \multirow{3}{*}{ C20:4 } & $7.3 \pm 1.01^{1}$ & $5.9 \pm 0.50^{1}$ & $8.2 \pm 0.86^{1}$ & $3.7 \pm 0.14^{1}$ \\
\hline & $4.7 \pm 0.02^{2}$ & $7.8 \pm 0.02^{2}$ & $10.5 \pm 0.30^{2}$ & - \\
\hline & $5.7 \pm 0.01^{3}$ & $6.3 \pm 0.01^{3}$ & $4.6 \pm 0.04^{3}$ & - \\
\hline \multirow{3}{*}{$\mathrm{C} 22: 4$} & $4.4 \pm 0.92^{1}$ & $1.0 \pm 0.12^{1}$ & $1.6 \pm 0.01^{1}$ & $2.0 \pm 0.02^{1}$ \\
\hline & $2.8 \pm 0.01^{2}$ & $4.3 \pm 0.01^{2}$ & $1.8 \pm 0.04^{2}$ & - \\
\hline & $3.2 \pm 0.20^{3}$ & $4.1 \pm 0.24^{3}$ & $4.5 \pm 0.05^{3}$ & - \\
\hline \multirow{3}{*}{$\sum$ Omega - 6} & $13.6 \pm 2.03^{1}$ & $10.0 \pm 0.73^{1}$ & $12.7 \pm 1.00^{1}$ & $10.4 \pm 0.17^{1}$ \\
\hline & $9.3 \pm 0.33^{2}$ & $15.5 \pm 0.04^{2}$ & $15.1 \pm 0.55^{2}$ & - \\
\hline & $11.4 \pm 0.25^{3}$ & $12.3 \pm 0.29^{3}$ & $12.8 \pm 0.43^{3}$ & - \\
\hline \multirow{3}{*}{$\sum$ PUFA } & $35.80 \pm 4.31^{1}$ & $31.2 \pm 3.97^{1}$ & $33.7 \pm 1.28^{1}$ & $26.9 \pm 0.30^{1}$ \\
\hline & $30.4 \pm 0.58^{2}$ & $41.7 \pm 0.18^{2}$ & $39.9 \pm 0.80^{2}$ & - \\
\hline & $34.4 \pm 2.00^{3}$ & $37.6 \pm 1.64^{3}$ & $36.9 \pm 2.03^{3}$ & - \\
\hline \multirow{3}{*}{ PUFA/SFA } & $0.88^{1}$ & $0.67^{1}$ & $0.58^{1}$ & $0.47^{1}$ \\
\hline & $0.83^{2}$ & $1.05^{2}$ & $1.28^{2}$ & - \\
\hline & $0.89^{3}$ & $0.96^{3}$ & $0.91^{3}$ & - \\
\hline \multirow{3}{*}{ Omega-3/Omega-6 } & $1.63^{1}$ & $2.12^{1}$ & $1.65^{1}$ & $1.59^{1}$ \\
\hline & $2.27^{2}$ & $1.69^{2}$ & $1.64^{2}$ & - \\
\hline & $2.02^{3}$ & $2.04^{3}$ & $1.88^{3}$ & - \\
\hline
\end{tabular}

NB: Data derived from analysis of Nile tilapia fish muscles. SFA: saturated fatty acids, MUFA: Monounsaturated fatty acids,

PUFA: polyunsaturated fatty acids. Values are averages of three replicates \pm standard deviation. The three values for each lipid under sampling sites represent samples collected during the 3 seasons: First entry ${ }^{1}$ - May 2010 samples, Second entry ${ }^{2}-$ November 2010 samples and Third entry ${ }^{3}-$ April $_{2011}$. The gaps under Kisati sampling sites are explained in 'Results' section.

Gulf of Lake Victoria. Generally the saturated fatty acids (SFAs) levels were highest in May 2010 compared to November 2010 and April 2011 levels.

\section{DISCUSSION}

Fish has been considered as a good indicator for heavy metal contamination in aquatic systems because they occupy different trophic levels with different sizes and ages. There 
was no significant difference $(p>0.05)$ in the levels of heavy metals analyzed in fish relative to the sampling sites although the analysis showed their presence in fish. This could be attributed to the fact that fish are mobile and keep on migrating from one place to the other. Zinc had the highest concentration of $40.0 \pm 0.5 \mathrm{mg} / \mathrm{kg}$ but this value is lower than the Codex guideline of $50 \mathrm{mg} / \mathrm{kg}$ given in food for fish [3]. Zinc is widespread among living organisms, due to its biological significance. The results obtained in this study for zinc are higher than some recent results reported by Öztürk, et al. [22] where some heavy metal concentrations of Cyprinus carpio fish samples from the Avşar Dam were analyzed. The high levels of lead $(\mathrm{Pb})(24.7 \pm 0.57 \mathrm{mg} / \mathrm{kg}) \mathrm{ob}-$ served in Dunga point fish (November 2010) could be coming from the water since Dunga water had significantly high levels of lead during the same sampling period. The guideline given for lead is $0.2 \mathrm{mg} / \mathrm{kg}$ and therefore lead levels in Winam Gulf fish exceed this guideline and may be posing some danger to consumers [22].

Cadmium levels were the lowest in fish. This could be due to the fact that cadmium has no biological role in living organisms. It induces kidney dysfunction, skeletal damage and reproductive deficiencies. According to European Commission, (EC, 2001) minimum value of cadmium in fish is $0.05 \mathrm{mg} / \mathrm{kg}$ [23]. The present study has shown that all the fish analyzed for cadmium exceed this guideline. Chromium was not detected in most sampling sites except in Kamito where it was $7.8 \pm 0.7 \mathrm{mg} / \mathrm{kg}$. The results from the present study were much higher than those reported by Abdel - Baki et al. where chromium levels in muscles of tilapia were 0.23 $\mathrm{mg} / \mathrm{kg}$ [24]. The chromium in Kamito could be coming from paints and dyes which are used by the communities living around the lake. Atmospheric deposition could also be contributing to these high levels.

Present results show that $\mathrm{Zn}$ metal was bioaccumulated most by the fish. However, current levels of $\mathrm{Zn}$ and $\mathrm{Cd}$ are much lower compared to those of Oreochromis niloticus muscles from Lake Manzala where $\mathrm{Zn}$ was found to be $212.44 \mathrm{mg} / \mathrm{kg}$ and $\mathrm{Cd}$ was $10.36 \mathrm{mg} / \mathrm{kg}$ [25]. Recent studies have shown the trend of accumulation of heavy metals in tilapia fish as: bone $>$ gills $>$ liver $>$ muscles [26]. Similar results were reported from a number of fish species which shows that muscle is not an active tissue in accumulating heavy metals $[22,27]$. This indicates clearly that the accumulation of heavy metals by fish is organ specific and therefore muscles are expected to accumulate lower levels of heavy metal pollutants than the other organs.

Saeed and Shaker [25] attributed the high accumulation of heavy metals in liver and gill tissues to the metallothionein proteins which are synthesized in liver and gill tissues when fish are exposed to heavy metals. These proteins are thought to play an important role in protecting them from damage by heavy metal toxicants. Also, gills are the sites directly exposed to the ambient conditions and are known for their excretory function even for some metals like zinc [26]. Moreover, Kebede, and Wondimu [26] reported that the amount of pollutants in the fish liver is directly proportional to the degree of pollution in the aquatic environment by heavy metals. The lower accumulation of heavy metals in muscles could be attributed to the fact that heavy metals are inorganic in nature and they will tend to be higher in bones than the lipophilic parts of fish such as the muscle. Fish can be considered as one of the most significant biomonitors in fresh water systems for the estimation of metal pollution; they offer several specific advantages in describing the natural characteristics of aquatic systems and assessing changes to habitats.

The trend in the heavy metals analyzed in fish from this study was: $\mathrm{Zn}>\mathrm{Pb}>\mathrm{Cr}>\mathrm{Cd}$. This kind of trend may be attributed to the abundance of these metals in Winam Gulf water and sediments by the same pattern. A similar trend was observed by Ongeri et al. [27] where muscles of Nile perch (Lates niloticus) were analyzed. The concentration levels of heavy metals in Winam Gulf show that the sediments act as the most important reservoir or sink for metals in the aquatic environment. Heavy metal contamination in sediments can affect the water quality and bioaccumulation of metals in aquatic organisms, resulting in potential longterm implication on human health and ecosystem [24]. The highest concentration of lead $(85 \pm 1.73 \mathrm{mg} / \mathrm{Kg})$ was recorded in Kisati where River Kisati discharges heavy loads of both industrial and municipal waste. These high levels of lead may have deleterious effects to the aquatic ecosystem in the long run since the metal is known to be toxic to all living organisms and plays no physiological role [22]. Lead values obtained in this study are lower than those reported about six years ago by Ochieng et al. [1] but were well above the levels recently reported in sediments in both Winam and Mwanza Gulfs [4]. These elevated levels can be attributed to anthropogenic sources especially from paints and leaded gasoline which spill from boats.

Zinc was significantly higher $(\mathrm{p}<0.05)$ in sediments with Kisati sampling point recording the highest levels of $277 \pm 1.53 \mathrm{mg} / \mathrm{kg}$ in November 2010 . This could be due to discharge of both industrial and municipal waste to the lake through River Kisati. Cadmium was significantly high $(3.3 \pm$ $0.50 \mathrm{mg} / \mathrm{kg}$ ) in Hippo point sediments in May 2010 (p < 0.05 ). Cadmium is widely used in paints and plastics and therefore this could be the source in form of municipal waste to the lake through a sewer line near Hippo point. Kamito sediments had elevated levels of chromium $(21.0 \pm 0.70$ $\mathrm{mg} / \mathrm{kg}$ ) in April 2011. These levels were lower than the ones reported in Kota Belud estuary in Malaysia where chromium levels in sediments were $36.06 \pm 3.23 \mathrm{mg} / \mathrm{kg}$ [28]. The high levels of chromium in Kamito could be coming from pigments and dyes since there is a lot of painting of buildings around the area.

There was a positive correlation $(\mathrm{p}<0.05)$ between $\mathrm{Zn}$ and $\mathrm{Pb} ; \mathrm{Zn}$ and $\mathrm{Cr}$ in sediments. This may be attributed to anthropogenic sources to the lake. Heavy metal distribution in sediments was in the order: $\mathrm{Zn}>\mathrm{Pb}>\mathrm{Cr}>\mathrm{Cd}$.

In water, lead levels ranged from $0.02-0.1 \pm 0.01 \mathrm{mg} / \mathrm{L}$ with the highest mean concentrations in Kisati sampling point $(0.1 \pm 0.01 \mathrm{mg} / \mathrm{L})$ in November 2010 short rains period. The current lead levels in water are lower than those previously reported in Winam Gulf which ranged from 0.15- 0.44 $\mathrm{mg} / \mathrm{L}$ [11]. Generally, the levels indicate very clearly that Kisati water is polluted with lead compared to Hippo, Dunga and Kamito waters. 
Kisati was identified previously as a major source of heavy metal pollutants to Winam Gulf emanating from municipal and industrial waste through River Kisati [8]. The lead concentration in Kisati water in November 2010 was well beyond both World Health Organization (WHO) [29] and Kenya Bureau of Standards (KEBS)[30] maximum allowed levels in drinking water of 0.01 and $0.05 \mathrm{mg} / \mathrm{L}$ respectively. The high lead concentrations in Lake Victoria waters at Kisati are probably due to lead from gasoline from the vehicles washed there, from acid of car batteries which find their way to the lake through the industrial and municipal discharge through River Kisati. Also lead could be coming from paints on the cars and boats and agricultural runoff since the sampling was done during the rainy season. Cadmium levels in water were significantly high $(0.02 \pm 0.00$ $\mathrm{mg} / \mathrm{L}$ ) in Hippo point in May 2010 and therefore this value was above the WHO set guideline of $0.003 \mathrm{mg} / \mathrm{L}$. For chromium the highest levels $(0.06 \mathrm{mg} / \mathrm{L})$ were recorded in Hippo point in April 2011. The WHO permissible level for chromium in drinking water is $0.05 \mathrm{mg} / \mathrm{L}$ and therefore Hippo point water had slightly higher levels than the guideline [29].

Results showing the percentage oil contents in the muscles of tilapia fish from Winam Gulf are represented in Table 1. Results of the present study were lower than recently reported values by Masa et al. [14] where the oil content from Nile tilapia was $5.23 \pm 0.47 \%$ and therefore was classified as semi- fatty fish. Oils from tilapia fish muscles from Winam Gulf were found to contain high proportions of long- chain omega - 3 PUFAs although the levels were lower than the standard menhaden oil ( $\omega-3,28.9 \%)$. Menhaden oil, which is marine fish oil, has been proposed by the United States Food and Drug administration (FDA), as a PUFA supplement [31]. Levels of EPA, C20: $5 n 3$ were lower than those of menhaden oil but comparable to the levels reported by Masa et al. [14]. DHA C22:6n3 levels were higher than the standard menhaden oil (6.2\%) except for fish from Kamito (May 2010) which had a lower value of $4.1 \pm 0.04 \mathrm{~mol} \%$. The differences in fatty acid levels in fish can be attributed to the fact that freshwater fishes feed largely on vegetation and plant materials such as microalgae, whereas marine fish feed on zooplanktons. Alpha linolenic acid C18:3 $n 3$ levels were similar to those reported by Kwetegyeka et al [32] for tilapia and Nile perch. Studies have shown that tilapia fish has the ability to bio-convert $\mathrm{C} 18$ fatty acids to highly unsaturated fatty acids (FAs) which are highly beneficial to human body [32].

Levels of arachidonic acid (AA) C20:4n6 were found to be higher than the levels of AA reported for tilapia fish from Ethiopian lakes [15]. This could be attributed to the diverse species of phytoplankton which the tilapia feeds on since they vary in size, nutrient content and digestibility. Arachidonic acid is a precursor for prostaglandin and thromboxane which influences blood clotting and its attachment to the endothelial tissue during wound healing and also plays a major role in growth [33]. Saturated fatty acids (SFA) content in Nile tilapia from the present study were higher than menhaden oil (20.8\%) [33]. Results from the current study also show that the SFA fraction was higher compared to the levels reported previously; where oil extracted from the belly flaps of Nile perch of varying sizes was analyzed for fatty acid composition [2]. The elevated SFA levels may be as a result of de novo synthesis within the fish, as well as the availability of large quantities of food for the fish. The total monounsaturated fatty acids (MUFA) levels obtained in this work were in agreement with those reported earlier on by Kwetegyeka et al. [32].

The ratios of omega -3 to omega - 6 PUFA $(1.59-2.27)$ from Nile tilapia were within the recommended range of 1 3 for fresh water fish whereas for marine fish the ratio is 8 18 [34]. Osman et al. [33] reported a ratio of 2.03 for the standard menhaden oil where he also suggested that it is a better index in comparing relative nutritional value of fish oils of different species. Thus, this key feature places the Nile tilapia analyzed in this study in the fresh water category and is in good agreement with those reported earlier by Masa et al. [14]. A high ratio of omega -3 to omega -6 PUFA in human and animal diets is very critical for proper physiological performance $[2,10]$.

The PUFA to SFA ratios $(0.47-1.28)$ observed in the present study were above the value $(0.58)$ recommended for dietary PUFA supplements by FDA [31] except for fish from Kisati sampling site which had the lowest value of 0.47. Ratio from the current study was also higher than 0.55 value reported by Mbatia et al. 2010 in Nile perch head [13]. A high ratio of PUFA to SFA indicates a good supply of PUFA relative to saturated fatty acids. Studies have shown that fish lipids with PUFA to SFA ratio above 0.5 have numerous health benefits which are attributed mainly to DHA and EPA [34]. Based on the high ratios of omega- 3 to omega -6 , Nile tilapia can be classified as a very good source of omega - 3 PUFA and therefore there is no need to concentrate the PUFA before human consumption. Oils from Nile tilapia can also be very ideal for production of omega -3 supplements after removal of heavy metal pollutants in case the levels are high maybe by chelation method. Generally, the results show that omega- 3 from Winam Gulf fish are adequate for healthy growth.

\section{CONCLUSIONS}

Sediment samples had the highest levels of heavy metals compared to water and fish samples. The trend of accumulation of heavy metal pollutants was: sediments $>$ fish $>$ water. From this study it was found that Lake Victoria water has high levels of $\mathrm{Pb}$ and $\mathrm{Cd}$ which are above WHO permissible levels in drinking water and it should be treated before drinking since people around the lake use it for domestic purposes.

The concentrations of heavy metals in fish muscles measured in this study provide baseline information on concentrations and distribution of metals in Tilapia fish from Winam Gulf of lake Victoria. Heavy metals showed some trend of accumulation in fish tissue indicating the importance of using fish as a bioindicator of aquatic pollution. The concentration of elements investigated in tilapia muscles were found to be higher than the guideline values of some European countries except for zinc which was lower than the maximum permissible level. There was no clear link between the levels of heavy metals in fish and the fatty acid levels although fish samples showed presence of these met- 
als. Therefore, tilapia fish from Winam Gulf of Lake Victoria can be consumed for omega -3 polyunsaturated fatty acids which are considered to have numerous health benefits and also the oils can be utilized for production of omega 3 supplements since the levels compare well with the standard menhaden oil which has been proposed as PUFA supplement. The present study focused on just one type of fish, Tilapia and samples were collected for one season to coincide with heavy rain (May, 2010), short rain (November, 2010) and dry (April 2011) seasons. Further studies that include more fish species represented in the lake using samples collected over a longer period of time, e.g. for three seasons is recommended. Such will clearly capture both seasonal and fish species variations, if any, which the present study was not able to establish. Otherwise, regular monitoring for heavy metal pollution status in this important water mass is critical for the health of those dependent on it for their livelihood.

\section{CONFLICT OF INTEREST}

The authors confirm that this article content has no conflicts of interest.

\section{ACKNOWLEDGEMENTS}

Funding was provided for by Lake Victoria research initiative (VicRes) through the Inter- university council of East Africa (ICUEA) for sustainable management of Lake Victoria resource. The University of Nairobi provided a lot of support by availing the required equipments to the team. The team is also very grateful to the management of Kenya Marine Fisheries institute (KMFRI), kisumu for the technical and logistical assistance offered during all the sampling times.

\section{REFERENCES}

[1] E. Z. Ochieng, J. O. Lalah, and S. O. Wandiga, "Heavy metals in water and surface sediments in Winam Gulf of Lake Victoria, Kenya”, Bull. Environ. Contam. Toxicol., vol. 77, pp. 459-468, 2006.

[2] P. Ogwok, J. H. Muyonga, M. L. Sserunjogi, A. K. Amegovu, and V. Makokha, "Variation in chemical composition of oils from Nile perch (Lates niloticus) Belly Flaps with capture site and season", $J$. Aquat. Food Prod. Technol., vol. 18, pp. 331-344, 2009.

[3] F. J. Muyodi, F. I. Mwanuzi, and R. Kapiyo, "Environmental quality and fish communities in selected catchments of Lake Victoria", Open Environ. Eng. J, vol. 4, pp. 54-65, 2011.

[4] D. O. Ogoyi, C. J. Mwita, E. K. Nguu, and P. M. Shiundu, “ Determination of heavy metal content in water, sediment and microalgae from Lake Victoria, East Africa", Open Environ. Eng. J., vol. 4, pp. 156-161, 2011.

[5] E. O. Okoth, W. Admiraal, O. Osano, V. Ngure, M. H. S. Kraak, and E. S. Omutange, "Monitoring exposure to heavy metals among children in Lake Victoria, Kenya: Environmental and fish matrix", Ecotoxicol. Environ. Saf., vol. 73, no. 7, pp. 1797-1803, 2010.

[6] J. O. Lalah, E. Z.Ochieng, and S. O. Wandiga, "Sources of heavy metal input into Winam Gulf, Kenya", Bull. Environ. Contam. Toxicol, vol. 81 (3), pp. 277-284, 2008.

[7] D. S. Kisamo, "Environmental hazards associated with heavy metals in Lake Victoria Basin (East Africa), Tanzania", Afr. Newslett. Occup. Health. Saf., vol. 13, pp. 67-69, 2003.

[8] D. M. Ongeri, J. O Lalah, K. W. Schramm, and B. Michalke, "Levels of toxic metals in multisectoral samples from Winam Gulf of Lake Victoria", Bull. Environ. Contam. Toxicol, vol. 82, pp. 64-69, 2009 .
[9] J. M.Onyari, and S. O.Wandiga, "Distribution of $\mathrm{Cr}, \mathrm{Pb}, \mathrm{Zn}, \mathrm{Fe}$, and $\mathrm{Mn}$ in Lake Victoria sediments, East Africa", Bull. Environ. Contam. Toxicol., vol. 42, pp. 807-813, 1989.

[10] P. Ogwok, J. H. Muyonga, and M. L Sserunjogi, "Pesticide residues and heavy metals in Lake Victoria Nile Perch Lates niloticus, Belly flap oil”, Bull. Environ. Contam. Toxicol., vol. 82, pp. 529533, 2009.

[11] M. P. Tole, and J. M. Shitsama, "Concentrations of heavy metals in water, fish, and sediments of the Winam Gulf", In: a paper presented at LVEMP conference, Kisumu, Kenya, 2001.

[12] B. Mbatia, P. Adlercreutz, F. Mulaa, and B. Mattiasson, "Enzymatic enrichment of n-3 polyunsaturated fatty acids in Nile perch (Lates niloticus) Viscera oil”, Eur. J. Lipid Sci. Technol., vol. 112, pp. 977-984, 2010.

[13] B. Mbatia, D. Adlercreutz, P. Adlercreutz, A. Mahadhy, F. Mulaa, and B. Mattiasson, "Enzymatic oil extraction and positional analysis of $\omega-3$ fatty acid in Nile perch and salmom heads", Process. Biochem., vol. 45, pp. 815-819, 2010.

[14] J. Masa, P. Ogwok, J. H. Muyonga, J. Kwetegyeka, V. Makokha, and D. Ocen , "Fatty acid composition of muscle, liver and adipose tissue of freshwater fish from Lake Victoria, Uganda", J. Aquat. Food. Prod. Technol., vol. 20, pp. 64-72, 2011.

[15] T. Zenebe, G. Ahlgren, and M. Boberg "Fatty acid content of some freshwater fish of commercial importance from tropical lakes in the Ethiopian Rift Valley", J. Fish Biol., vol. 53, pp. 987-1005, 1998.

[16] APHA, Standard Methods for the Examination of Water and Wastewater, $18^{\text {th }}$ ed. American Public Health Association: Washington, 1992.

[17] L. H. Keith, Environmental Sampling and Analysis: a Practical Guide, $1^{\text {st }}$ ed. CRC press LLC: Florida, 1938.

[18] M. A. Kishe, and J. F. Machiwa, "Distribution of heavy metals in sediments of Mwanza Gulf of Lake Victoria, Tanzania", Environ. Int., vol. 28, pp. 619-625, 2003.

[19] W.W. Christie, and X. Han, lipid analysis. Isolation, Separation, Identification and Lipidomic Analysis, $4^{\text {th }}$ ed. The Oily Press Bridgewater UK, 2010.

[20] D. A. Skoog, F. J. Holler, and T.A. Nieman, "Principles of Instrumental Analysis", $5^{\text {th }}$ ed. Thomson Brooks/Cole: Belmont, CA, 1998, pp. 701-720.

[21] J. M. Keriko, C. W. Chege , M.M. Magu, E.C. Mwachiro, A. N.Murigi, M. N.Githua, and P. G. Kareru, "Fish lipid contents and classes of selected fish species found in Lake Naivasha (Kenya) and the fish feeding habits of the lake's inhabitants", Afri. J.Pharm. Pharmacol., vol. 4, pp.745-753, 2010.

[22] M. Öztürk, G. Özözen, O. Minareci, and E. Minareci, "Determination of heavy metals in fish, water and sediments of Avsar dam lake in Turkey", Iran. J. Environ. Health. Sci. Eng., vol. 6, no. 2, pp. 73-80, 2009.

[23] M. Malakootian, M. Tahergorabi, M. Daneshpajooh, and K. Amirtaheri, "Determination of $\mathrm{Pb}, \mathrm{Cd}, \mathrm{Ni}$, and $\mathrm{Zn}$ Concentrations in Canned Fish in Southern Iran", Sacha J.Environ. Stud., vol. 1, pp. 94-100, 2011.

[24] A. S. Abdel-Baki, M. A. Dkhil, and S. Al-Quraishy, "Bioaccumulation of some heavy metals in tilapia fish relevant to their concentration in water and sediment of Wadi Hanifah, Saudi Arabia", Afr. J. Biotechnol., vol. 10, no. 13, pp. 2541-2547, 2011.

[25] S. M. Saeed, and I. M. shaker, "Assessment of heavy metals pollution in water and sediments and their effect on Oreochromis niloticus in the northern delta lakes, Egypt", In: $8^{\text {th }}$ International Symposium on Tilapia in Aquaculture, 2008.

[26] A. Kebede, and T. Wondimu, "Distribution of trace elements in muscle and organs of tilapia, Oreochromis niloticus, from Lakes Awassa and Ziway, Ethiopia”, Bull. Chem. Soc. Ethiop., vol. 18, no. 2, pp.119-130, 2004.

[27] D. M. K Ongeri, J. O. Lalah. S. O. Wandiga, K. Schramm, and B. Michalke, "Trace metals in Lates niloticus and Rastrineobola argentea samples for human consumption at Winam Gulf of Lake Victoria", Toxicol. Environ. Chem., vol. 91, no. 2, pp. 233-240, 2009

[28] M. H. Abdullah, J. Sidi, and A. Z. Aris ,"Heavy Metals $(\mathrm{Cd}, \mathrm{Cu}$, $\mathrm{Cr}, \mathrm{Pb}$ and $\mathrm{Zn}$ ) in Meretrix meretrix Roding, Water and Sediments from Estuaries in Sabah, North Borneo", Int.J.Environ. Sci. Educ., vol. 2, no. 3, pp. 69-74, 2007. 
[29] WHO. Guidelines for drinking water quality international program on chemical safety, vol. 2, World Health Organization: Geneva, 1996.

[30] KEBS, Kenya Bureau of Standards, KS 05-459: part 1, pp. 6, ICS 13.060.20, 1996.

[31] FDA. "Food and Drug Administration. Food labeling: Requirements for nutrient content claims, health claims, and statements of nutritional support for dietary supplements", Fed. Regist. - Rules Regul., vol. 62,pp. 49859-49868, 1997.
[32] J. Kwetegyeka, G. Mpango, and O.G. Niesen, "Variation in fatty acid composition in muscle and heart tissues among species and populations of tropical fish in Lakes Victoria and Kyoga", Lipids, vol. 43, pp. 1017-1029, 2008.

[33] H. Osman, A. R. Suriah, and E. C. Law, "Fatty acid composition and cholesterol content of selected marine fish in Malaysian waters", Food. Chemist., vol. 73, pp. 55-60, 2001.

[34] O. Grahl-Nielsen, E. Averina, N. Pronin, L. Radnaeva, and R. Käkelä, "Fatty acid profiles in different fish species in Lake Baikal", Aquat. Biol., vol. 13, no. 1, pp. 1-10, 2011.

Received: July 01, 2013

Revised: August 13, 2013

Accepted: August 15, 2013

(C) Muinde et al.; Licensee Bentham Open.

This is an open access article licensed under the terms of the Creative Commons Attribution Non-Commercial License (http://creativecommons.org/licenses/by-nc/3.0/g) which permits unrestricted, non-commercial use, distribution and reproduction in any medium, provided the work is properly cited. 